\title{
IDENTIFIKASI LEVEL KINERJA NOVICE MELALUI KEMAMPUAN BERPIKIR KRITIS SISWA (INTERPRETASI, ANALISIS)
}

\author{
Indah Rahayu Panglipur1, Eric Dwi Putra ${ }^{2}$ \\ Pendidikan Matematika, IKIP PGRI Jember ${ }^{1,2}$
}

indah.ikipjember@gmail.com¹, dwieric454@gmail.com²

\begin{abstract}
Abstrak
Aspek yang mempunyai peranan penting di dalam pendidikan adalah pembelajaran, sehingga perlu untuk dikembangkan supaya dapat menggali potensi dalam diri siswa sehingga diharapkan dapat menciptakan lulusan yang berkualitas dari proses pengajaran yang telah dilaksanakan oleh guru. Setiap diri siswa bisa dilatih untuk kemampuan kritisnya serta selalu ditingkatkan. Jenis penelitian yang dipakai dalam penelitian ini merupakan penelitian kualitatif menggunakan pendekatan deskriptif. Subjek diambil berdasarkan nilai ulangan harian yang telah terdokumentasi oleh guru matematika. Teknik pengambilan data menggunakan tes dan wawancara. Berdasarkan hasil penelitian diketahui bahwa level kinerja novice melalui kemampuan berpikir kritis yaitu pada aspek interpretasi siswa tidak bisa menyajikan permasalahan sesuai soal dalam bentuk bahasa matematika dengan jelas dan pada aspek analisis siswa tidak menuliskan informasi yang terdapat pada soal serta siswa sudah dapat menuliskan konsep namun masih salah atau tidak sesuai.
\end{abstract}

Kata kunci: level kinerja Novice, kemampuan berpikir kritis, interpretasi, analisis

\begin{abstract}
The aspect that has an important role in education is learning, so it needs to be developed in order to explore the potential in students so that it is expected to create quality graduates from the teaching process that has been implemented by the teacher. Every student can be trained for their critical abilities and always be improved. This type of research used in this study is a qualitative study using a description approach. Subjects were taken based on daily test scores that have been documented by the mathematics teacher. Data collection techniques using tests and interviews. Based on the result of this study known that the level of novice performance through the ability to think critically that the aspect of student interpretation can not present problems according to questions in the form of mathematical language clearly and in the analysis aspect students do not write the information contained in the questions and students can write the concept however is still wrong or incompatible.
\end{abstract}

Keywords: Novice performance level, critical thinking ability, interpretation, analysis 


\section{PENDAHULUAN}

Perkembangan teknologi saat ini yang begitu pesat akan sangat berdampak pada dunia pendidikan. Oleh karena itu, dengan adanya perkembangan teknologi yang pesat ini akan mengakibatkan berkembangnya suatu ilmu pengetahuan yang dapat berdampak positif maupun sebaliknya yaitu mempunyai dampak negatif. Dunia Pendidikan merupakan bagian dari fondasi untuk kemampuan ilmu pengetahuan maupun teknologi. Aspek yang mempunyai peranan penting didalam pendidikan adalah pembelajaran, sehingga perlu untuk dikembangkansupaya dapat menggali potensi dalam diri siswa sehingga diharapkan dapat menciptakan lulusan yang berkualitas dari proses pengajaran yang telah dilaksanakan oleh guru. Hal tersebut sangat dibutuhkan proses pembelajaran yang mempunyai sifat universal yang mendasari dari perkembangan teknologi modern, serta memiliki peran penting untuk berbagai disiplin ilmu. Pelajaran matematika merupakan salah satu yang memiliki peran penting dalam perkembangan teknologi.

Pelajaran Matematika merupakan salah satu mata pelajaran yang wajib diberikan terhadap siswa yang bertujuan untuk memberi bekal untuk kemampuan berpikir logis, sistematis, analitis, kreatif, kritis serta memiliki kemampuan untuk bekerjasama didalam proses pembelajaran. Pembelajaran matematika yang berkembang dewasa ini, selalu menuntut agar siswa dapat aktif didalam proses pembelajaran, selain itu juga menuntut keterampilan setiap siswa untuk dapat mengolah data yang telah diberikan oleh guru di setiap pelaksanaan proses pembelajaran. Yang dimaksud Keterampilan didalam pembelajaran matematika tidak hanya terbatas pada kemampuan berhitung, tetapi juga untuk keterampilan proses pada pengembangan kemampuan berpikir (Destino \& Bharata, 2019).

Berpikir adalah segala aktivitas mental yang membantu merumuskan atau memecahkan masalah, membuat keputusan atau memenuhi keinginan untuk memahami (Irawan, Susanto, \& Kurnianti, 2015). Setiap Siswa Mempunyai Kemampuan berpikir yang berbeda-beda, hal tersebut bergantung bagaimana siswa tersebut melatih serta mengembangkan kemampuan berpikir tersebut. Berpikir kritis merupakan salah satu dari bentuk kemampuan berpikir dan setiap siswa harus miliki kemampuan berpikir kritis.

Menurut Ennis (Sari, Susiswo, \& Nusantara, 2017) berpikir kritis adalah berpikir logis dan reflektif yang difokuskan pada pengambilan keputusan yang akan dipercayai atau dilakukan. Setiap diri siswa bisa dilatih untuk kemampuan kritisnya serta selalu ditingkatkan secara rutin untuk menyelesaikan suatu permasalahan matematika yang membutuhkan pengetahuan tingkat tinggi, dan salah satunya yaitu dengan cara 
mengoptimalkan pada kemampuan kinerja siswa. Pemecahan masalah selalu melibatkan proses berpikir serta usaha. Usaha tersebut yang bisa dimaksimalkan terhadap siswa dengan suatu pengalaman pengetahuan yang siswa sudah miliki sehingga kemampuan kinerja tersebut akan meningkat.

Penilaian kinerja merupakan salah satu proses untuk mengetahui seberapa besar penguasaan siswa pada materi matematika di sekolah. Menurut (Meutia, Hifzi \& Ahmad, 2013) penilaian kinerja merupakan suatu teknik penilaian yang dipergunakan untuk bisa mengetahui suatu tingkat penguasaan keterampilan terhadap siswa melalui tes penampilan maupun demonstrasi serta praktik kerja nyata. Salah satu level dari kinerja siswa yaitu Novice.

Level Kinerja Novice merupakan level kinerja yang paling rendah. Hal ini disebabkan karena pada level ini, sorang siswa benar-benar tidak mempunyai strategi dalam proses menyelesaikan masalah, alasan serta proses dalam melakukan pembuktian tanpa memberikan suatu penjelasan yang bersifat logis berdasarkan konsep-konsep matematika maupun sains. Seorang guru perlu mengetahui level kinerja Novice supaya jika seorang siswa terjadi masalah tentang strategi dalam menyelesaikan masalah, serta pembuktian bisa segera ditemukan sehingga siswa dapat menyelesaikan masalah pada pelajaran matematika. Selain itu perlunya seorang guru untuk mengetahui siswa yang berada pada kinerja Novice agar materi yang menjadi dasar atau prasyarat jika terjadi masalah bisa segera ditemukan dan pada materi pembelajaran matematika berikutnya, seorang siswa tidak mengalami kesulitan dalam proses menyelesaikan masalah serta proses dalam melakukan pembuktian.

\section{METODE PENELITIAN}

Jenis penelitian yang dipakai dalam penelitian ini merupakan penelitian kualitatif (Moleong, L, 2012) menggunakan pendekatan deskripsi. Peneliti tertarik untuk mengadakan identifikasi level kinerja Novice pada siswa kela VII dalam menyelesaikan soal matematika berdasarkan kemampuan berpikir kritis siswa pada materi bilangan dengan indikator interpretasi dan analisis. Peneliti akan mengidentifikasi level kinerja siswa dalam berpikir kritis pada subjek yang telah ditentukan. Subjek diambil berdasarkan nilai ulangan harian yang telah terdokumentasi oleh guru metamatika kelas VII. Subjek dikelompokan menjadi kemampuan rendah (KR), kemampuan sedang (KS), dan kemampuan tinggi (KT). Dari masingmasing tingkat kemampuan diambil 1 orang sehingga total subjek yang dilibatkan dalam penelitian ini ada 3 orang subjek. Teknik pengambilan data menggunakan tes dan wawancara. Pelaksanaan tes sebanyak 1 kali dan pelaksanaan wawancara dilakukan 1 kali setelah dilaksanakan tes. Instrumen 
soal tes dan lembar wawancara dilakukan uji validitas isi terlebih dahulu. Menurut Hobri (IR Panglipur, 2019), menentukan rerata hasil validasi dari semua validator untuk setiap indikator dengan rumus:

$$
I_{i}=\frac{\sum_{j=1}^{n} V_{j i}}{v}
$$

dengan :

$V_{j i}=$ data nilai dari validator ke-j terhadap indikator ke- $i$

$j=$ validator

$i=$ indikator

$v=$ banyaknya validator

Dengan nilai $I_{i}$, kemudian ditentukan nilai rerata untuk setiap aspek $A_{i}$ dengan persamaan:

dengan :

$$
A_{i}=\frac{\sum_{i=1}^{m} I_{i}}{m}
$$

$A_{i}=$ nilai rerata aspek

$I_{i}=$ rerata nilai untuk aspek ke- $i$

$i=$ aspek yang dinilai

$m$ = banyaknya aspek

Dengan nilai $A_{i}$, kemudian ditentukan nilai rerata total untuk semua aspek $V_{a}$ dengan persamaan :

dengan :

$$
V_{a}=\frac{\sum_{i=1}^{n} I_{i}}{n}
$$

$V_{a}=$ nilai rerata total semua aspek

$I_{i}=$ rerata nilai untuk aspek ke- $i$

$i=$ aspek yang dinilai

$n$ = banyaknya aspek

Hasil $V_{a}$ yang diperoleh kemudian ditulis pada kolom yang sesuai, juga dalam tabel tersebut. Instrumen dinyatakan valid dan dapat digunakan jika nilai $V_{a} \geq 2,5$.

Tabel 1 Kriteria Validitas Instrumen

\begin{tabular}{cc}
\hline Nilai $V_{a}$ & Tingkat Kevalidan \\
\hline$V_{a}=3$ & Sangat Valid \\
\hline $2,5 \leq V_{a}<3$ & Valid \\
\hline $2 \leq V_{a}<2,5$ & Cukup Valid \\
\hline $1,5 \leq V_{a}<2$ & Kurang Valid \\
\hline $1 \leq V_{a}<1,5$ & Tidak Valid \\
\hline
\end{tabular}

Hasil tes dilihat dari lembar jawaban siswa dalam mengerjakan soal. Jawaban siswa diidentifikasi melalui lembar identifikasi berdasarkan 
indikator standar berpikir kritis, kemudian dikategorikan dalam level kinerja siswa sesuai pedoman penskoran level kinerja siswa yang masuk pada level Novice. Setelah selesai dilakukan penyimpulan dengan rerata total skor tiap indicator (Putra \& Panglipur, 2019).

Tabel 2 Kategori Level Kinerja Siswa

\begin{tabular}{cc}
\hline Nilai $\boldsymbol{x}$ & Level Siswa \\
\hline$x=4$ & Expert \\
\hline $3 \leq x<4$ & Practitioner \\
\hline $2 \leq x<3$ & Apprentice \\
\hline $1 \leq x<2$ & Novice \\
\hline
\end{tabular}

Pengecakan keabsahan data dilakukan dengan menggunakan triangulasi metode. Triangulasi yang dimaksud hasil data dari tes dikuatkan dengan dukungan data hasil pelaksanaan wawancara.

\section{HASIL DAN PEMBAHASAN}

Data pertama yang diperoleh adalah hasil validasi instrumen soal tes dan wawancara. Hasil validasinya adalah sebagai berikut. Nilai $V_{\text {apada }}$ soal tes adalah 2,8 dikatakan valid sesuai dengankriteria bila masuk berada pada kategori valid jika 2,5 $\leq V_{a}<3$. Sedangkan nilai $V_{a}$ pada wawancara adalah 2,6 , dikatakan valid sesuai dengankriteria bila masuk berada pada kategori valid jika $2,5 \leq V_{a}<3$.

Subjek penelitian dikodekan dengan KT pada siswa kemampuan tinggi, KS pada siswa kemampuan Sedang, KR pada siswa kemampuan Rendah. Pada ketiga subjek diberikan soal tes sejumlah 3 soal. Sedangkan hasil subjek diberikan soal tes dan wawancara. Dari hasil tes diperoleh data bahwa level Novice melalui kemampuan berpikir kritis (Interpretasi dan Analisis) dapat dilihat sesuai masing-masing subjek.

Tabel 3 Hasil Kemampuan Berpikir Kritis KR

\begin{tabular}{cll}
\hline Subjek & Standar kritis & \multicolumn{1}{c}{ Indikator } \\
\hline KR & Interpretasi & a. Siswa tidak menuliskan yang diketahui \\
& & dalam soal. \\
& b. Siswa tidakbisa menyajikan permasalahan \\
& sesuai soal dalam bentuk bahasa \\
& matematika dengan jelas \\
\cline { 2 - 3 } & a. Siswa tidak menuliskan informasi yang \\
& terdapat pada soal \\
& b.Siswa sudah dapat menuliskan konsep \\
& namun masih salah/tidak sesuai \\
\end{tabular}

Berdasarkan tabel 3 yaitu data hasil kemampuan berpikir siswa dengan kemampuan rendah terlihat bahwa pada tahap interpretasi siswa belum dapat memahami soal sehingga tidak dapat mengerjakan apapun baik mulai dari hal-hal yang diketahui pada soal sampai pada penyajian permasalahan yang ada pada soal tersebut. Kemampuan berpikir seprti ini 
memperlihatkan bahwa siswa memang benar-benar belum memahami materi dan belum memahami isi soal. Dengan kondisi siswa seperti ini perlu adanya pembimbingan lebih intensif oleh guru agar siswa tidak mengalami tertinggal materi. Jika tidak segera dilakukan pembimbingan oleh guru maka subjek KR akan semakin tertinggal jauh.

Tabel 4 Hasil Kemampuan Berpikir Kritis KS

\begin{tabular}{|c|c|c|}
\hline Subjek & Standar kritis & Indikator \\
\hline \multirow[t]{2}{*}{ KS } & Interpretasi & $\begin{array}{l}\text { a. Siswa dapat menuliskan yang diketahui } \\
\text { namun masih ada beberapa yang belum } \\
\text { tepat dan tidak sesuai dengan soal } \\
\text { b. Siswa cukup bisa menyajikan } \\
\text { permasalahan yang sesuai soal dalam } \\
\text { bentuk bahasa matematika meskipun masih } \\
\text { belum terlalu terperinci dan jelas }\end{array}$ \\
\hline & Analisis & $\begin{array}{l}\text { a. Siswa dapat menuliskan informasi namun } \\
\text { masih ada yang kurang tepat } \\
\text { b. Siswa sudah dapat menuliskan konsep } \\
\text { dengan tepat dan benar }\end{array}$ \\
\hline
\end{tabular}

Berdasarkan Tabel 4 yaitu data hasil kemampuan berpikir siswa dengan kemampuan sedang terlihat pada tahap interpretasi siswa sudah dapat memahami soal sehingga sudah dapat mengerjakan beberapa hal yang diketahui namun demikian masih terdapat kesalahan dan kurang tepat. Selain itu siswa sudah cukup terampil menyajikan permasalahan yang terdapat pada soal dalam bahasa matematika. Namun masih belum terlalu terperinci dan lengkap sehingga guru tinggal mengarahkan dan membimbing untuk lebih teliti dan cermat lagi dalam membaca dan mengartikal kata serta maksud dalam setiap soal. Informasi yang disajikan siswa sudah cukup baik meskipun belum lengkap dan kurang tepat. Sedangkan untuk penulisna konsep siswa sudah mulai bisa dituliskan dengan tepat dan benar.

Tabel 5 Hasil Kemampuan Berpikir Kritis KT

Subjek Standar kritis Indikator

\begin{tabular}{|c|c|c|}
\hline \multirow[t]{2}{*}{ KT } & Interpretasi & $\begin{array}{l}\text { a. Siswa dapat menuliskan yang diketahui } \\
\text { dengan tepat dan sesuai dengan soal } \\
\text { secara berurutan } \\
\text { b. Siswa cukup bisa menyajikan } \\
\text { permasalahan yang sesuai soal dalam } \\
\text { bentuk bahasa matematika dengan } \\
\text { terperinci dan jelas }\end{array}$ \\
\hline & Analisis & $\begin{array}{l}\text { a. Siswa dapat menuliskan informasi dengan } \\
\text { tepat dan benar } \\
\text { b. Siswa sudah dapat menuliskan konsep } \\
\text { dengan tepat dan benar }\end{array}$ \\
\hline
\end{tabular}


Berdasarkan Tabel 5 data hasil kemampuan berpikir siswa dengan kemampuan tinggi terlihat pada tahap interpretasi siswa sudah dapat memahami soal dengan baik terlihat dapat menuliskan yang diketahui dengan tepat dan sesuai. Selain itu juga dapat menyajikan permasalahan dalam bentuk bahsa matematika dengan terperinci dan jelas. Pada tahap analisis siswa dapat menuliskan informasi dengnatepat dan benar dari soal yang telah diberikan. Informsai yang dituliskan dapat disajikan dengan baik dan mudah dipahami. Setelah memahami soal siswa sudah dapat menuliskan konsep matematika yang didapat dari soal dengan benar tepat dan sesuai materi yang diberikan.

Penelitian dilanjutkan dengan mengadakan wawancara pada masingmasing subjek. Kegiatan wawancara dilakukan pada saat di luar jam pelajaran. Adapun hasil wawancara dalah sebagai berikut.

Subjek KR menyampaikan bahwa memang tidak mengerti maksud dari soal. Hanya membaca soal saja tanpa paham maksud soal tersebut. Sehingga siswa menyampaikan mengerjakan seadanya kalau tidak paham tidak dikerjakan sama sekali

Subjek KS bercerita bahwa memahami sedikit maksud dari permasalah pada soal sehingga mencoba menuliskan sesuai dengan yang dipahaminya. Memang tidak paham secara keseluruhan tapi berusaha mengisi pada jawaban.

Subjek KT sudah sangat memahami dengan baik soal dan permasalahan yang disajikan. Siswa tidak mengalami kesulitan mulai dari awal mengerjakan sampai pada kesimpulan penulisan konsep yang tertuang dalam soal. Siswa sangat yakin bahwa jawabannya benar.

Dari hasil tes dan wawancara dilakukan uji keabsahan data dengan hasil bahwa adanya kesesuain data yang diperoleh. Pada masing-masing unsur saling mendukung dan menguatkan. Maka data hasil kedua metode ini bisa dipergunakan secara keseluruhan.

\section{KESIMPULAN DAN SARAN}

Kesimpulan yang dapat diambil dari kegiatan penelitian ini adalah level kinerja novice melalui kemampuan berpikir kritis yaitu pada aspek interpretasi siswa tidak bisa menyajikan permasalahan sesuai soal dalam bentuk bahasa matematika dengan jelas dan pada aspek analisis siswa tidak menuliskan informasi yang terdapat pada soal serta siswa sudah dapat menuliskan konsep namun masih salah/tidak sesuai. Saran yang dapat diberikan yaitu sebaiknya guru memperhatikan level kinerja novice siswa terhadap berpikir kritisnya agar kualitas pembelajaran lebih bagus. 


\section{DAFTAR PUSTAKA}

Destino, M. D., \& Bharata, H. (2019). Pengembangan Bahan Ajar Transformasi Geometri Berorientasi pada Kemampuan Bepikir Kritis Siswa. 10(1), 5767.

IR Panglipur, E. P. (2019). Analisis Level Kinerja Expert Melalui Kemampuan Berpikir Kritis. Emasians, VIII, 24-29.

Irawan, D., Susanto, \& Kurnianti, D. (2015). Pelevelan Kinerja Siswa berdasarkan Kemampuan Berpikir Kritis Siswa Kelas VII MTS Negeri Jember dalam Menyelesaikan Soal matematika yang terkit Tema Kopi. Kadikma, 6(3), 57-66.

Meutia, Hifzi, R. J., \& Ahmad, A. (2013). Kemampuan Mahasiswa Calon Guru Menerapkan Penilaian Kinerja Untuk Menilai Hasil Belajar Siswa Dalam Pembelajaran Matematika. Jurnal Peluang, 1(2).

Moleong,L, J. (2012). Metodologi Penelitian Kualitatif Edisi Revisi. Bandung: PT Remaja Rosdakarya.

Sari, M., Susiswo, \& Nusantara, T. (2017). Analisis Kemampuan Berpikir Kritis Siswa Kelas Viii-D Smp Negeri 1 Gambut. Prosiding Seminar Nasional Pendidikan Sains (SNPS), (November), 232-236.

Putra, E. D., \& Panglipur, I. R. (2019). Analisis Level Kinerja Practitioner melalui Aktivitas Belajar Siswa. Jurnal Pendiidkan Matematika (JUDIKA EDUCATION), 2(1), 25-35. 